\title{
Recenzje
}

DOI $10.14746 / \mathrm{ssp} .2017 .1 .14$

\section{Katarzyna Kosowska, Rosyjski sektor naftowy wobec no- wych wyzwań na rynku krajowym i zagranicznym, Wydaw- nictwo Księgarnia Akademicka, Kraków 2016, ss. 194.}

Funkcjonowanie oraz perspektywy rozwoju sektora naftowego Federacji Rosyjskiej, uwzględniając, z jednej strony, znaczenie tej gałęzi przemysłu dla gospodarki rosyjskiej, z drugiej zaś strony, eksport tego surowca do Polski stanowią ciekawy obszar badawczy, który w Polsce jest analizowany w sposób wyrywkowy. Niewątpliwie, książka Katarzyny Kosowskiej Rosyjski sektor naftowy wobec nowych wyzwań na rynku krajowym i zagranicznym, w pewnym sensie wypełnia lukę na polskim rynku wydawniczym w odniesieniu do analizy kierunku ewolucji rosyjskiego przemysłu naftowego. Jednocześnie, uwzględniając rolę surowców energetycznych, które wielokrotnie w przeszłości były wykorzystywane jako narzędzie do realizacji celów politycznych, wydaje się, że to zagadnienie powinno być jednym z kluczowych obszarów zainteresowań ośrodków badawczych zajmujących się w Polsce m.in. współczesną polityką zagraniczną Rosji. Z całą pewnością potrzeba prowadzenia badań nad tego typu zagadnieniami wydaje się niezwykle trafna przede wszystkim z powodów poznawczych - wiedza na temat kierunków rozwoju przemysłu naftowego jednego z największych eksporterów ropy naftowej na świecie umożliwia kształtowanie odpowiednich decyzji politycznych.

Recenzowana publikacja składa się ze spisu treści, siedmiu rozdziałów, zakończenia, bibliografii, indeksu osobowego oraz streszczenia w języku angielskim. W poszczególnych rozdziałach Autorka przeanalizowała znaczenie sektora naftowego w gospodarce Rosji, zasoby surowcowe, wielkości wydobycia i eksportu ropy naftowej oraz czynniki ograniczające funkcjonowanie tej branży przemysłu. Przyjęta struktura pracy budzi jednak spore wątpliwości. Po pierwsze - poszczególne rozdziały różnią się objętościowo w sposób znaczący (ponad połowę publikacji stanowi jeden z rozdziałów). Po drugie - układ chronologiczny rozdziałów wydaje się mało czytelny. W pierwszej kolejności zasadne byłoby opisanie zasobów surowcowych Federacji Rosyjskiej, wskazanie na wielkość 
wydobycia i eksportu ropy naftowej, a dopiero w dalszej kolejności opisywanie znaczenia sektora naftowego dla gospodarki rosyjskiej oraz czynników wpływających na rozwój branży wydobywczej. Po trzecie - niektóre rozdziały zostały wyznaczone w sposób mało logiczny (fragmenty pracy, w których zostały opisane wydobycie ropy naftowej oraz struktura segmentu wydobywczego powinny stanowić jedną spójną całość). W efekcie monografia sprawia wrażenie chaotycznej i mało przemyślanej pod względem strukturalnym, co burzy klarowność prezentowanych wywodów.

Przygotowany wstęp stanowi wprowadzenie do analizowanej problematyki, w którym Autorka zaprezentowała krótko sytuację rosyjskiego sektora naftowego oraz w zwięzły i przystępny sposób opisała wpływ wahań cen ropy naftowej z lat 2014-2016 na gospodarkę rosyjską. Niemniej w tej części pracy odczuwalny był brak m.in. celów publikacji, uzasadnienia dla zastosowanego kryterium wyodrębnienia rozdziałów oraz zakresu czasowego. Niewątpliwie w szczególności w pracy powinien zostać wskazany horyzont czasowy, gdyż Autorka w wielu miejscach formułując swoje stwierdzenia używa czasu teraźniejszego, co powoduje różne nieścisłości i trudności w odpowiednim zrozumieniu fragmentów tekstu [np. „prognozy sprzed dwóch lat” (s. 9), „w ciagu ostatnich czternastu lat” (s. 16), „W chwili obecnej” (s. 78), ,w ostatnich latach” (s. 83)].

W rozdziale pierwszym Autorka zaprezentowała znaczenie branży naftowej dla gospodarki Federacji Rosyjskiej, przychody, jakie generuje handel tym surowcem, a także opisała debatę na temat roli surowców energetycznych w krajowej gospodarce. Odnosząc się do rozważań zawartych w tym rozdziale można sformułować jedną uwagę, przy czym o charakterze drugorzędnym niemającym wpływu na jakość tego fragmentu publikacji. Prezentując dyskusję na temat modelu gospodarki Rosji, Autorka nie dokonała krytycznej analizy formułowanych koncepcji oraz oceny zasadności i szans na realizację surowcowo-innowacyjnego rozwoju kompleksu paliwowo-energetycznego, a więc dominującego współcześnie sposobu traktowania m.in. sektora naftowego przez władze w Rosji (s. 23-27).

W rozdziale drugim Autorka opisała w sposób syntetyczny funkcjonowanie rosyjskich państwowych funduszy majątkowych. W ciekawy sposób zaprezentowała ich specyfikę, funkcję jaką spełniają w rosyjskiej gospodarce oraz ewolucję ich powstawania. Dodatkowo opisała zmianę wielkości zgromadzonych środków finansowych w okresie kryzysów ekonomicznych (2008-2009 oraz 2014-2015). Poprawnie Autorka zauważa, że w sposób szczególny spadek cen ropy naftowej, który rozpoczął się w czerwcu 2014 roku miał istotny wpływ na wielkość zgromadzonych w Rosji środków finansowych. Niemniej w tej części pracy brakuje autorskiego komentarza oceny wpływu wydarzeń z 2014 roku na funkcjonowanie funduszy inwestycyjnych oraz perspektyw ich istnienia w zmienionych uwarunkowaniach.

W rozdziale trzecim Autorka w sposób klarowny scharakteryzowała rosyjskie obszary występowania ropy naftowej (prowincje naftowe), a także najważniejsze 
współcześnie regiony wydobycia tego surowca. Przeprowadzone w tej części rozważania nasuwają jednak pewne zastrzeżenia. Dokonując prezentacji danych w zakresie rosyjskich zasobów ropy naftowej, korzystnym rozwiązaniem byłoby podanie informacji o wielkości rosyjskich złóż na tle innych państw (s. 55). Opisując poziom sczerpania rosyjskich złóż ropy naftowej, Autorka podała błędne dane (s. 61-63), wskazując poziom nawet 90\% (światowy współczynnik sczerpania dla pojedynczego złoża ropy naftowej wynosi ok. 40\%) (The Importance). W tym przypadku chodzi zatem o poziom możliwej do wyeksploatowania ropy naftowej. Jednocześnie należy wskazać, iż w rozdziale tym Autorka charakteryzując poszczególne prowincje naftowe prezentuje inne dane dotyczące m.in. poziomu wydobycia ropy naftowej, co utrudnia możliwość swobodnego porównania pojedynczych regionów. W tej części publikacji zostały dodatkowo przedstawione błędne dane dotyczące zasobów (10 mld ton) oraz wielkości możliwego do wydobycia surowca (100 mld ton) ze złóż rosyjskiego szelfu arktycznego (s. 67). W rzeczywistości większą wartość powinny stanowić zasoby, a mniejszą potencjalna wielkość wydobycia. W tym fragmencie książki odczuwalny był również brak komentarza w zakresie perspektyw i szans dotyczących możliwości eksploatacji ropy naftowej ze złóż niekonwencjonalnych (s. 72-74). Dlatego też oprócz opisu obszarów występowania tego typu złóż zasadne byłoby określenie przez Autorkę potencjalnego wpływu wydobycia ropy naftowej ze złóż niekonwencjonalnych na politykę naftową Federacji Rosyjskiej.

W rozdziałach czwartym, piątym i szóstym Autorka zaprezentowała w sposób rzeczowy i zwięzły informacje dotyczące poziomu wydobycia ropy naftowej, eksportu tego surowca oraz struktury segmentu wydobywczego. Przeprowadzone w tych częściach rozważania nad rynkiem ropy naftowej nasuwają dwie refleksje. Po pierwsze - z uwagi na ograniczone informacje zawarte w poszczególnych rozdziałach niezrozumiałe było zaprezentowanie ich w trzech odrębnych fragmentach tekstu. Po drugie - w rozdziale szóstym, w celu przedstawienia pełnej informacji na temat struktury segmentu wydobywczego, zasadne byłoby scharakteryzowanie poszczególnych spółek wydobywczych w porównywalny sposób, co zwiększyłoby przejrzystość wywodów oraz uzupełnienie tego fragmentu książki o informacje dotyczące firm serwisowych, gdyż ich funkcjonowanie ma istotne znaczenie dla branży naftowej w Rosji.

W rozdziale siódmym Autorka w ciekawy sposób przeanalizowała czynniki, które stanowią współcześnie ograniczenie rozwoju branży wydobywczej w Rosji. W interesujący sposób zostały przedstawione informacje na temat wpływu polityki fiskalnej oraz sankcji nałożonych na Federację Rosyjską w związku z aneksją Półwyspu Krymskiego oraz wojną rosyjsko-ukraińską (wsparcie przez Rosję separatystów we wschodniej części Ukrainy). Jednocześnie warto podkreślić, że była to część pracy, która nie wzbudziła znaczących zastrzeżeń.

Zakończenie książki stanowi syntetyczne podsumowanie badań przeprowadzonych przez Autorkę. W tej części opracowania niezwykle ciekawe byłoby określenie prawdopodobnych scenariuszy rozwoju sytuacji na rosyjskim rynku 
energetycznym, z uwagi na zmieniające się uwarunkowania zewnętrzne (wahania cen ropy naftowej, politykę wielu państw w zakresie ograniczenia emisji szkodliwych substancji do atmosfery oraz zmniejszenia udziału paliw kopalnych w bilansach energetycznych).

Prezentowane zagadnienia wzbogacono licznymi wykresami (szesnaście) oraz tabelami (dwadzieścia sześć), które zwiększyły klarowność analizowanych problemów. Niemniej jednak pewnym mankamentem był brak podania źródła, na podstawie których zostały przygotowane niektóre z nich (wykresy - s. 84, 85,135 oraz tabele - s. 115-116, 139). Jednocześnie, z uwagi na liczbę wykresów i tabel rozsądne byłoby umieszczenie w publikacji odpowiednich spisów. Dla zwiększenia przejrzystości przedstawianych rozważań zasadne byłoby także umieszczenie w publikacji wykresów w kolorze, ponieważ niektóre z nich są mało czytelne.

Analizując warstwę językową i stylistyczną zasadne wydaje się zwrócenie uwagi, iż w tekście w sposób niewłaściwy zostały użyte niektóre sformułowania, w tym o charakterze publicystycznym, takie jak ,gospodarka jest zakładniczką" (s. 10), ,zarobiwszy na eksporcie” (s. 15), ,pełni funkcję motoru rosyjskiej gospodarki” (s. 13, 26), „barki naftowców” (s. 19), „szło opornie” (s. 23), ,przypuszczenia ministra” (s. 52), „Minister Finansów planuje zużytkować” (s. 52), „naftodolarów” (s. 45), „wysoki poziom niejasności na rynkach” (s. 49), „lwią część” (s. 78, 114, 140), „słabą stroną prognoz” (s. 82), „Rosja pomyślnie realizuje swoją strategię” (s. 88), ,zasady gry” (s. 101), ,poważne projekty” (s. 103), „marnotrawienie spadku po ZSRR i brak troski” (s. 105), ,eksperci uprzedzali o mylności takiego kroku” (s. 126), ,projekty ustaw zostały odwołane” (s. 150), „budżet wygra na nowej reformie” (s. 155), „sankcje zachodnie zadadzą mocny cios” (s. 162), „dostęp do skarbów Arktyki” (s. 164), „drzwi dla produkcji chińskiej otworzą się” (s. 169), „stawić czoło” (s. 173), „Rosja wygrała jedynie poszczególne bitwy" (s. 176). Dodatkowo Autorka błędnie opisała skrót Organizacji Współpracy Gospodarczej i Rozwoju, jako OWGR (w rzeczywistości powszechnie stosownym w literaturze skrótem jest wyraz angielski OECD - Organization for Economic Co-operation and Development).

Recenzowana monografia stanowi interesujące studium funkcjonowania rosyjskiego rynku naftowego oraz wyzwań, przed jakimi stoi sektor wydobywczy. Niemniej jednak w publikacji był odczuwalny brak w niektórych miejscach rozważań Autorki na temat wpływu analizowanych zjawisk i zachodzących procesów na przyszłą rosyjską politykę naftową (ograniczona liczba ocen oraz zdań autorskich). Dlatego też w dużej mierze w publikacji opisano podejmowane działania, ale bez określenia oraz wskazania konsekwencji ich realizacji (np. budowa monopolu, decentralizacja przemysłu w kierunku kilku konkurujących przedsiębiorstw energetycznych), co stanowiłoby interesujące uzupełnienie informacji zawartych w książce.

Rekapitulując, pomimo wyeksponowanych nieścisłości i błędów należy wskazać, że recenzowane opracowanie zasługuje na uwagę. Publikacja K. Ko- 
sowskiej jest wartościowa pod względem poznawczym oraz faktograficznym i z tego też względu jest godna polecenia badaczom, którzy zajmują się polityką zagraniczną Rosji oraz bezpieczeństwem energetycznym.

\section{Bibliografia}

The Importance of EOR, http://www.slb.com/services/technical_challenges/enhanced_oil_recovery.aspx, 10.02.2017.

Michat PASZKOWSKI

Warszawa 
